\title{
Case of a lung collision tumor consisting of squamous cell carcinoma of the lung and diffuse large B-cell lymphoma
}

Masato SASAKI ( $\square$ masato@u-fukui.ac.jp )

University of Fukui https://orcid.org/0000-0002-9999-7984

\section{Kayo SAKON}

Fukui University of Health Sciences: Fukui Iryo Daigaku

\section{Kaede TANAKA}

University of Fukui Faculty of Medical Sciences

\section{Tae MIZUNAGA}

University of Fukui Faculty of Medical Sciences

\section{Keita YANO}

University of Fukui Faculty of Medical Sciences

\section{Yuuko KAWAMURA}

University of Fukui Faculty of Medical Sciences

\section{Akitoshi OKADA}

University of Fukui Faculty of Medical Sciences

\section{Takeshi IKEDA}

National Center for Global Health and Medicine

\section{Sawaka TANABE}

University of Fukui Faculty of Medical Sciences

\section{Atsushi TAKAMORI}

University of Fukui Faculty of Medical Sciences

Narihisa YAMADA

Universityof Fukui Faculty of Medical Sciences

\section{Kouichi MORIOKA}

University of Fukui Faculty of Medical Sciences

\section{Takaaki KOSHIJI}

University of Fukui Faculty of Medical Sciences

\section{Case report}

Keywords: Collision tumor, mixed tumor, double tumor, non-small cell lung cancer, primary lung cancer, malignant lymphoma 
DOI: https://doi.org/10.21203/rs.3.rs-146992/v1

License: (c) (i) This work is licensed under a Creative Commons Attribution 4.0 International License. Read Full License 


\section{Abstract}

\section{Background}

The collision tumor consisted of two malignant tumors that independently developed and were contiguous or had invaded each other. Among the reports of malignant collision tumors, collision tumors consisting of lung cancer and malignant lymphoma are extremely rare. We report case of a lung collision tumor consisting of squamous cell carcinoma of the lung and diffuse large B-cell lymphoma.

\section{Case presentation}

A 74-year-old man was admitted to the hospital due to identification of an abnormal nodular shadow in the right upper lobe on chest computed tomography following a chest X-ray. At the time of admission, a swollen lymph node of $7 \mathrm{~cm} \times 5 \mathrm{~cm}$ was palpated in the left neck, and serum examination showed an abnormally high level of soluble interleukin-2 receptor. Close examination led to a diagnosis of stage IA squamous cell carcinoma of the lung and stage IVA malignant lymphoma, and treatment for the malignant lymphoma was prioritized. However, due to progression of lung cancer, a right upper lobectomy with lymph node dissection was performed. Pathological findings showed that squamous cell carcinoma and malignant lymphoma were both present in the same lesion.

\section{Conclusion}

Only two cases of collision tumors consisting of malignant lymphoma and primary lung cancer were reported [1] [2] and this case is considered to be the third rare case in the world. As the rate of complications with other malignancies in patients with diffuse large B-cell lymphoma is high, in the case of advanced stage malignant lymphoma, physicians must consider which treatment should be prioritized according to the degree of progression of coexisting solid tumors.

\section{Background}

Among the reports of malignant collision tumors, collision tumors consisting of lung cancer and malignant lymphoma are extremely rare [1] [2]. Here, we report a resected case of a collision tumor that included squamous cell carcinoma of the lung and malignant lymphoma.

\section{Case Presentation}

A 74-year-old male presented with a right upper nodule on chest X-ray. He was admitted to our hospital for the purposes of close examination and treatment. Chest computed tomography (CT) revealed a nodular shadow in the upper right lobe. Smoking history was 1 pack/day $\times 55$ years.

Clinical characteristics: Height: $169.7 \mathrm{~cm}$, weight: $72.4 \mathrm{~kg}$, body temperature: $36.1{ }^{\circ} \mathrm{C}$, pulse rate: 88 beats/min, blood pressure: $120 / 66 \mathrm{mmHg} \mathrm{SpO}_{2}: 98 \%$, elastic soft and well-moving lymphadenopathy of $7 \times$ $5 \mathrm{~cm}$ in the left neck. No other special notes.

Laboratory data (Table 1): 
Red blood cell count showed mild anemia. CRP, LDH, ALP, NSE, and soluble interleukin-2 receptor (sIL-2R) were elevated.

Imaging findings:

Chest X-ray (Fig. 1A): A nodular shadow of approximately $2 \mathrm{~cm}$ maximum diameter was found in the upper right lung field.

Chest CT (Fig. 1B): A $24 \times 21 \times 18 \mathrm{~mm}$ nodule with a cavity was found in Segment 1 of the upper right lobe.

Fluorodeoxyglucose-positron emission tomography (FDG-PET) (Fig. 1C): A maximum standardized uptake value (SUV) accumulation of 9.4 was observed in the nodule of the right upper lobe. In addition to strong accumulation in the left cervical lymph nodes, accumulation also occurred in both axillary lesions, near the pancreatic head, in both external iliac arteries, and in the right inguinal lymph nodes.

Clinical Course:

Bronchoscopy was performed to assess the lung lesions, and squamous cell carcinoma of the lung was diagnosed. Malignant lymphoma was diagnosed from a left cervical lymph node biopsy. At this point, the clinical stage of the lung cancer was stage IA, and the stage of malignant lymphoma was stage IVA, and thus, treatment for malignant lymphoma was given priority. After two courses of R-CHOP (Rituximab + cyclophosphamide + hydroxydaunorubicin + vincristine + prednisolone) therapy for malignant lymphoma, slL2R normalized to 466 from $14003 \mathrm{U} / \mathrm{ml}$. However, chest radiographs and chest CT revealed nodular shadows in the right upper lung field that had increased, and new cavities appeared. On FDG-PET, maximum SUV in the lung tumor increased from 9.4 to 10.5 , but accumulation in the lymphoma lesions remained only in the left inguinal region, with little accumulation in other areas. Surgery was then performed for the lung cancer. Another reason for the surgery for the lung cancer was discontinuation of chemotherapy due to relapse of hepatitis B. In April 2013, a right upper lobectomy and mediastinal lymph node dissection was performed for his lung cancer. The lesion was a white lobulated mass approximately $33 \mathrm{~mm}$ in size with cavitation.

Pathological findings (Figs. 2A, B, C):

Poorly differentiated squamous cell carcinoma of the lung and malignant lymphoma-like lesions were observed in the same foci (Fig. 2A). Immunohistochemical staining revealed that CD79a (Fig. 2B right), a Bcell marker, was positive, indicating diffuse large B-cell lymphoma. In addition, the area where AE1AE3 (Fig. 2C right), which is an epithelial marker, was positive and the area where CD79a was positive overlapped, suggesting that squamous cell carcinoma and malignant lymphoma were both present in the same lesion (Fig. 2B, 2C right). After the operation, eight courses of R-CHOP therapy were performed. However, the malignant lymphoma worsened, and $2 \mathrm{nd}$ - and $3 \mathrm{rd}$-line treatments were attempted. However, the disease was not controlled, and he died 10 months after the operation.

\section{Discussion And Conclusions}


To the best of our knowledge, this is the third case in the world of a collision tumor that consisted of malignant lymphoma and primary lung cancer. As far as we could search for such collision tumors, 3 cases were found (Table 1). But in Case no.4 [3] shown in Table 1, lung adenocarcinoma with malignant lymphoma as one of the lesions of systemic metastasis cannot be said to be a collision tumor in the strict sense.

Meyer et al.[4] and Foulds et al.[5] classified collision tumors in the same organ into three categories. The first is a collision tumor in which two malignant tumors have independently developed and are contiguous or have invaded each other. The second is a combination tumor consisting of multiple morphologies that originated from a common mother cell. The third is a constituent tumor in which a relationship between the parenchyma and the stroma is present. This case is considered the first category of collision tumor. The mechanism of the occurrence of such collision tumors in lung squamous cell carcinoma and malignant lymphoma depends on certain factors that facilitate formation of a collision tumor. Hypotheses include: (a) Chronic irritation of lung tissue by malignant lymphoma causes lung squamous cell carcinoma. (b) Immune deficiency in the lung due to malignant lymphoma and a microcirculation disorder in the mucous membrane cause carcinogenesis. (c) Malignant lymphoma is caused by a direct chronic immunological reaction to lung cancer. (d) Common carcinogens for both tumors are likely present. A case of lung adenocarcinoma with malignant lymphoma in one of the foci of systemic metastasis was reported as case 4 shown in Table 1 [3]. The author suggested that this case was not a collision tumor in the strict sense that a solid tumor metastasized throughout the whole body, and a portion of it was found in a lesion of malignant lymphoma. Pure collision tumors are those in which each tumor develops independently, mixes with the other, and invades, as in the first category mentioned above.

Collision cancers including digestive organ cancer and malignant lymphoma have also been reported $[6,7,8$, 9]. Collision cancers, which consist of gastrointestinal cancer and malignant lymphoma, tend to be more common than cancers in other organs. Generally, double cancers of gastrointestinal malignancies account for $5-20 \%$ of non-Hodgkin's lymphomas and $30-40 \%$ of extra-nodal lymphomas $[10,11]$. In contrast, double cancers of primary malignant lymphoma of the lung are rare due to the apparently small absolute number of $0.3 \%$ of non-Hodgkin's lymphomas [12].

Both the lungs and digestive tract are organs that function in the presence of external substances such as bacteria and eliminate them. The immune system is present in both organs. The digestive tract is exposed to more external substances than the lungs, and the immune system is enhanced for that purpose [13]. The authors speculate that collision tumors that include gastrointestinal tract tumors and lymphomas are more common because of the higher exposure to external substances. The coexistence of pulmonary adenocarcinoma and malignant lymphoma in the same location is an extremely rare event $[1,2]$.

Some reports have been published of collision cancers consisting of different histological types of lung cancer.[14, 15, 16] This type of collision tumor belongs to the second category mentioned by Foulds [12]. In these cases, two collision cancers with the same disease but different histological types are present, a situation that is less of a therapeutic problem. A clinical problem occurs, for example, when the diseases are different, such as malignant lymphoma and a solid cancer, and treatment is prioritized for the more advanced tumor. As in our case, we prioritized the treatment of malignant lymphoma, but due to advancing lung cancer, surgery became necessary. 
The collision tumor is a special type of double tumor. The rate of complications with other malignancies in patients with diffuse large B-cell lymphoma is $15.2 \%$ [17]. Therefore, in the case of advanced stage malignant lymphoma, physicians must consider which treatment should be prioritized according to the degree of progression of coexisting solid tumors.

\section{Conclusion}

We experienced a case in which squamous cell carcinoma of the lung and malignant lymphoma were mixed in the same lesion. Chemotherapy was performed, but lung cancer worsened, and surgery was performed. Following surgery, chemotherapy was continued. Two cases of collision tumors consisting of malignant lymphoma and primary lung cancer were reported, and this case is the third rare case in the world.

\section{Abbreviations}

Standardized uptake value; SUV, Fluorodeoxyglucose-positron emission tomography; FDG-PET, soluble interleukin-2 receptor; sIL-2R, R-CHOP; Rituximab + cyclophosphamide + hydroxydaunorubicin + vincristine + prednisolone

\section{Declarations}

\section{Acknowledgements}

The authors acknowledge the contribution of patients involved in this study.

\section{Authors' contributions}

M Sasaki, K Sakon and T Ikeda are the attending physicians for this case. M Sasaki is responsible for the concept and design of this study, and everything.

The co-authors contributed to the acquisition and interpretation of the reference.

M SASAKI drafted the study and other co-authors revised it. All authors approve the publication of the manuscript and agree to take responsibility. All authors reviewed, edited, and agreed on the final draft of the manuscript.

\section{Funding}

This work did not receive any grants from funding agencies in the public, commercial, or not-for-profit sectors.

\section{Availability of data and materials}

The dataset is available upon request.

\section{Ethics approval and consent to participate}


We obtained informed consent from the patient for permission to publish his clinical information as a case report. The present study was conducted in accordance with the World Medical Association Declaration of Helsinki. As this study was a retrospective case study and did not include any potentially identifiable patient data, the institutional review board gave the ethics approval for this retrospective case report.

\section{Consent for publication}

All authors have provided their consent for publication of this manuscript.

\section{Competing interests}

None of the authors have stated that they have no conflicts of interest.

\section{References}

1. Kawashima O, Sakata S, Kamiyoshihara M, Maeshima A, Ishikawa S, Morishita Y. Primary pulmonary collision tumor including squamous cell carcinoma and T-cell lymphoma. Lung Cancer. 1999;23(1):6770. https://doi: 10.1016/s0169-5002(98)00100-7

2. C Du, F Gao, E Wen, X Liu, L Du, F Luo. Successful treatment of coexistence of diffused large $B$ cell lymphoma and lung adenocarcinoma, a case report. Int J Gerontology. 2016;10(4):242-244. https://doi.org/10.1016/j.ijge.2016.07.001

3. S Ikemura, M Moriyama, K Matsumoto, S Nakayama, T Matsuzaki, T Nakajima, et al. Lymph Node Collision Tumor Consisting of Metastatic Pulmonary Adenocarcinoma and Diffuse Large B-cell Intern Med 2018;57:1135-1139. https://doi.org/10.2169/internalmedicine.9280-17

4. Meyer, R. Beitrang zur Verstanding uber die Namengebung in der Geschwulstleher. Zentralbl. Allg Path Anat 1919;30: 291-296, http://doi.NAID:10025555327

5. Foulds L. The histological analysis of tumors. Am. J. Cancer 1940;39:1-24. http://doi.ID 194122005893.

6. Fukuda H, Morisawa T, Yamazaki T, Hishiya E, Deguchi M, Minami N, et al. A case of a collision tumor comprising gastric cancer and a malignant lymphoma treated by endoscopic submucosal dissection. Nippon Shokakibyo Gakkai Zasshi. 2018;115(10):923-929. https://doi.org/10.11405/nisshoshi.115.923

7. N Tsujiura, S Nakamura, S Nakao, S Ootake, K Kobayashi, T Matsuda: A case of a coexisting adenocarcinoma and a malignant lymphoma of the stomach. Japanese Journal of Cancer Clinics 1991; 37(1):60-64. https://doi: J-GLOBAL ID $\$ 200902038939940838$

8. H-H Lin, J-K Jiang, J-K Lin. Collision tumor of low-grade B-cell lymphoma and adenocarcinoma with tuberculosis in the colon: a case report and literature review. World Journal of Surgical Oncology 2014;12:147-151. https://doi: 10.1186/1477-7819-12-147.

9. S Murakami, Y Uchida, N Kubo, Y Hiraoka, T Noguchi, K Matsumoto, et al. A Case of Collison Tumor with Squamous Cell Carcinoma and Malignant Lymphoma in the Cardia. The Japanese Journal of Gastroenterological Surgery 1994;27(12):2574-77. https://doi.org/10.5833/jjgs.27.2574

10. Nakamura $S$, Matsumoto T, lida $M$, Yao T, Tsuneyoshi M. Primary gastrointestinal lymphoma in Japan: a clinicopathological analysis of 455 patients with special reference to its time trends. Cancer 
2003;97:2462-73. https://doi.10.1002/cncr.11415.

11. F d'Amore, H Brincker, K Grønbaek, K Thorling, M Pedersen, M K Jensen, et al. Non-Hodgkin's lymphoma of the gastrointestinal tract: a population-based analysis of incidence, geographic distribution, clinicopathologic presentation features, and prognosis. Danish Lymphoma Study Group. J Clin Oncol 1994;12:1673 - 84. https://doi. 10.1200/JC0.1994.12.8.1673

12. Freeman C, Berg JW, Culter SJ. Occurrence and prognosis of extranodal lymphomas. Cancer 1972;29:252-260. https://doi.org/10.1002/1097-0142(197201)29:1<252::AIDCNCR2820290138>3.0.C0;2-\%23

13. K Hosomi, J Kunisawa. Immunological Crosstalk with Gut Environmental Factors for The Development of Mucosal Vaccine and Immunotherapy. The Journal of Farm Animal in Infectious Disease 2015;4(2):21-28. http://doi.kachikukansen.org/kaiho2/PDF/4-2-21.pdf

14. S Nakata, Y Nagata, M Sugaya, M Yasuda, T Yamashita, M Takenoyama, et al. Primary Pulmonary Collision Cancer Consisting of Large Cell Carcinoma and Adenocarcinoma. The Annals of Thoracic Surgery 2005;80(1): 340-342. https://doi.org/10.1016/j.athoracsur.2003.12.053

15. M Takenaka; T Hanagiri; F Hirai; H Uramoto; M Takenoyama; K Yasumoto. Two Resected Cases of Collision Cancer of the Lung. Haigan 2010; 50(3):308-312. https://doi.10.2482/haigan.50.308

16. N Rekhtman, L Borsu, B Reva, G J. Riely, M Ladanyi, A Drilon, Unsuspected Collision of Synchronous Lung Adenocarcinomas. A Potential Cause of Aberrant Driver Mutation Profiles. Journal of Thoracic Oncology 2014;9(1): E1-E3. https://doi.org/10.1097/JTO.0b013e3182a471c3

17. K Tanba, Y Chinen, H Uchiyama, N Uoshima, K Shimura, S Fuchida, et al., J Kuroda. Prognostic impact of a past or synchronous second cancer in diffuse large B cell lymphoma. Blood Cancer Journal (2018) 8:1 https://doi 10.1038/s41408-017-0043-6

\section{Tables}

Table 1: Laboratory data on admission 


\begin{tabular}{|c|c|c|c|c|c|c|c|c|}
\hline \multicolumn{9}{|c|}{ Bloodcellcount } \\
\hline WBC & 4800 & $/ \mu l$ & $\mathrm{Na}$ & 136 & $\mathrm{mEq} / \mathrm{l}$ & T-Bil & 0.4 & $\mathrm{mg} / \mathrm{dl}$ \\
\hline RBC & $4.11 \times 106$ & $/ \mu l$ & $\mathrm{~K}$ & 4.1 & $\mathrm{mEq} / \mathrm{l}$ & AST & 30 & $\mathrm{U} / \mathrm{I}$ \\
\hline $\mathrm{Hb}$ & 13.7 & $\mathrm{~g} / \mathrm{dl}$ & $\mathrm{Cl}$ & 103 & $\mathrm{mEq} / \mathrm{I}$ & ALT & 21 & $\mathrm{U} / \mathrm{I}$ \\
\hline Plt & $244 \times 103$ & $/ \mu l$ & $\mathrm{Ca}$ & 8.6 & $\mathrm{mg} / \mathrm{dl}$ & $\mathrm{LDH}$ & 416 & $\mathrm{U} / \mathrm{I}$ \\
\hline CRP & 1.50 & $\mathrm{mg} / \mathrm{dl}$ & UN & 12 & $\mathrm{mg} / \mathrm{dl}$ & ALP & 746 & $U / I$ \\
\hline FBS & 104 & $\mathrm{mg} / \mathrm{dl}$ & $\mathrm{Cr}$ & 0.58 & $\mathrm{mg} / \mathrm{dl}$ & Y-GTP & 24 & $U / I$ \\
\hline \multicolumn{3}{|c|}{ tuomr marker } & \multicolumn{3}{|c|}{ arterial gas } & \multicolumn{3}{|c|}{ Infectious data } \\
\hline CEA & 1.5 & $\mathrm{ng} / \mathrm{ml}$ & $\mathrm{pH}$ & 7.403 & & HCV Ab. & $(-)$ & \\
\hline SCC & 0.7 & $\mathrm{ng} / \mathrm{ml}$ & $\mathrm{pCO} 2$ & 40.5 & $\mathrm{mmHg}$ & HBs ab. & $(-)$ & \\
\hline CYFRA 19 & 1.1 & $\mathrm{ng} / \mathrm{ml}$ & p02 & 82.3 & $\mathrm{mmHg}$ & Hbe ag. & $(-)$ & \\
\hline Pro-GRP & 30.6 & $\mathrm{pg} / \mathrm{ml}$ & $\mathrm{HCO} 3$ & 24.7 & $\mathrm{mmol}$ & Hbe ab. & $(+)$ & \\
\hline SLX & 34.1 & $\mathrm{U} / \mathrm{ml}$ & B.E. & 0.5 & $\mathrm{mmol}$ & HBc ab. & $(+)$ & \\
\hline NSE & 20.7 & $\mathrm{ng} / \mathrm{ml}$ & & & & & & \\
\hline sIL-2R & 5862 & $\mathrm{U} / \mathrm{ml}$ & & & & & & \\
\hline
\end{tabular}

Table 2 Cases of collision tumors primary malignant lymphoma and primary lung cancer reported 


\begin{tabular}{|c|c|c|c|c|c|c|}
\hline Source & year & $\begin{array}{l}\text { Age } \\
\text { Sex }\end{array}$ & $\begin{array}{l}\text { Lung cancer } \\
\text { Histology } \\
\text { Pathological- } \\
\text { Stage }\end{array}$ & $\begin{array}{l}\text { Malignant } \\
\text { Lymphoma } \\
\text { Pathological- } \\
\text { Stage }\end{array}$ & treatment & Prognosis \\
\hline $\begin{array}{l}\text { O } \\
\text { Kawashima } \\
\text { et al.[1] }\end{array}$ & 1998 & $\begin{array}{l}71 \\
\text { Female }\end{array}$ & $\begin{array}{l}\text { Squamous cell } \\
\text { carcinoma } \\
\text { T2aNOM0 } \\
\text { StagelB }\end{array}$ & $\begin{array}{l}\text { T-cell } \\
\text { Lymphoma }\end{array}$ & $\begin{array}{l}\text { Operation } \\
\text { CHOP }\end{array}$ & $\begin{array}{l}7 \text { months } \\
\text { death } \\
\text { after the } \\
\text { operation }\end{array}$ \\
\hline $\begin{array}{l}\text { C Du et al. } \\
\text { [2] }\end{array}$ & 2016 & $\begin{array}{l}60 \\
\text { Female }\end{array}$ & Adenocarcinoma & $\begin{array}{l}\text { Diffuse large } \\
\text { B cell } \\
\text { lymphoma }\end{array}$ & $\begin{array}{l}\text { CDDP+Gemcitabine } \\
\rightarrow \mathrm{CHOP}\end{array}$ & Alive \\
\hline $\begin{array}{l}\text { S lkemura } \\
{[3]}\end{array}$ & 2018 & $\begin{array}{l}67 \\
\text { Male }\end{array}$ & $\begin{array}{l}\text { Adenocarcinoma } \\
\text { T4N3M1 } \\
\text { Stage IV }\end{array}$ & $\begin{array}{l}\text { Diffuse large } \\
\text { B cell } \\
\text { lymphoma }\end{array}$ & $\begin{array}{l}\text { Chemotherapy not } \\
\text { administered }\end{array}$ & $\begin{array}{l}\text { 17th day } \\
\text { death } \\
\text { after } \\
\text { admission }\end{array}$ \\
\hline Our case & 2020 & $\begin{array}{l}74 \\
\text { Male }\end{array}$ & $\begin{array}{l}\text { Squamous cell } \\
\text { carcinoma } \\
\text { T1aNOM0 } \\
\text { Stage IA }\end{array}$ & $\begin{array}{l}\text { Diffuse large } \\
\text { B cell } \\
\text { lymphoma } \\
\text { Stage IVA }\end{array}$ & Operation $\mathrm{CHOP}$ & $\begin{array}{l}10 \\
\text { months } \\
\text { death } \\
\text { after the } \\
\text { operation }\end{array}$ \\
\hline
\end{tabular}

\section{Figures}



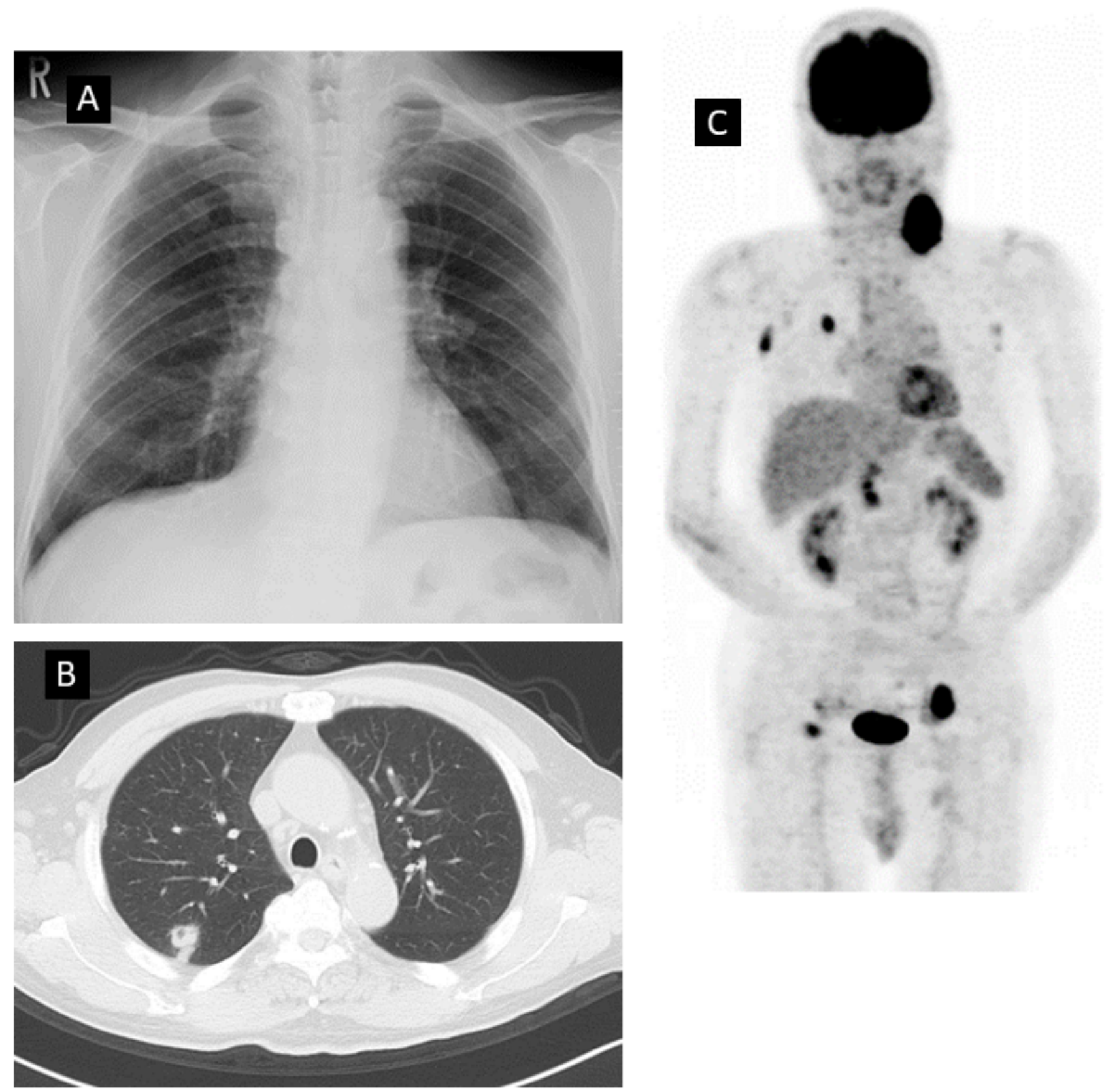

Figure 1

A: Chest X-ray: A nodular shadow approximately $2 \mathrm{~cm}$ in maximum diameter was found in the upper right lung field. B: Chest CT: A $24 \times 21 \times 18 \mathrm{~mm}$ nodule with a cavity was found in the first segment of the upper right lobe. C: FDG-PET: SUVmax accumulation of 9.4 was observed in the nodule in the right upper lobe. In addition to strong accumulation in the left cervical lymph nodes, accumulation also occurred in both axillary lesions, near the pancreatic head, in both external iliac arteries, and in the right inguinal lymph nodes. 

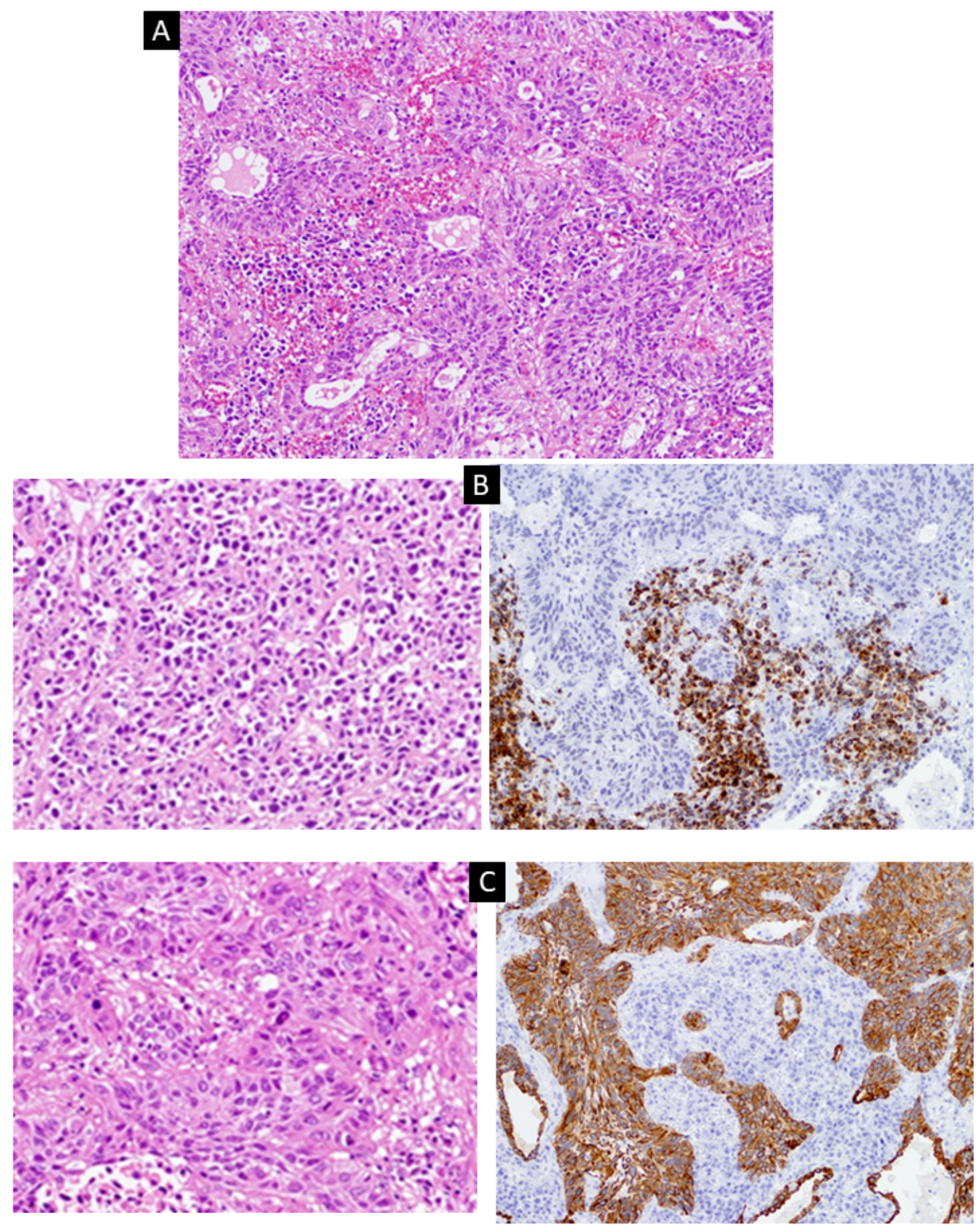

Figure 2

A (top, $x 20)$ : Pathological findings: Poorly differentiated squamous cell carcinoma of the lung and malignant lymphoma-like lesions were observed in the same foci (upper) B (middle), 2C (bottom):

Immunohistochemical staining revealed that CD79a (2B right, $\mathrm{x} 20$ ), a B-cell marker, was positive, indicating diffuse large B-cell lymphoma. In addition, the area where AE1AE3 ( $2 \mathrm{C}$ right, $\mathrm{x} 20)$, which is an epithelial marker, was positive and the area where CD79a was positive overlapped, suggesting that squamous cell 
carcinoma and malignant lymphoma were both present in the same lesion. The left side of 2B (malignant lymphoma) and $2 \mathrm{C}$ (squamous cell carcinoma) shows hematoxylin-eosin staining (x10). 